\title{
Regional Tourism at the Cross-Roads: Perspectives of Caribbean Tourism Organization's Stakeholders
}

\author{
Berneece Herbert ${ }^{1} \&$ Colmore S. Christian ${ }^{2}$ \\ ${ }^{1}$ Department of Community and Regional Planning, College of Agricultural, Life and Environmental Sciences, \\ Alabama A\&M University, Alabama, USA \\ ${ }^{2}$ Forestry, Ecology and Wildlife Program, College of Agricultural, Life and Environmental Sciences, Alabama \\ A\&M University, Alabama, USA \\ Correspondence: Colmore S. Christian, Department of Community and Regional Planning, College of \\ Agricultural, Life and Environmental Sciences, Alabama A\&M University, Alabama, USA. E-mail: \\ colmore.christian@aamu.edu
}

Received: September 15, 2013 Accepted: December 5, 2013 Online Published: December 27, 2013

doi:10.5539/jsd.v7n1p17 URL: http://dx.doi.org/10.5539/jsd.v7n1p17

\begin{abstract}
The Caribbean has experienced considerable fluctuations with many of the small island-nations of the Region being highly vulnerable to socio-political, environmental and economic changes. The Caribbean Tourism Association (CTO) contends that this Region is highly dependent on tourism, possibly more than any other region in the world, but globalization has left the countries of the Region with limited economic alternatives. The result is that tourism has emerged as the largest employer and the foremost foreign exchange earner in the Region. This survey research study, data from which were analyzed with SPSS for Windows, explored three research questions and identified the Region's strengths, assets and issues as perceived by stakeholders at the CTO's 2010 Sustainable Tourism Conference. People, culture and favorable weather were identified as strengths. However, critical issues such the absence of clear political and policy directions, loss of biodiversity and natural resources, need for more efficient zoning and land use planning for integrated tourism development, and insufficient stakeholder involvement were characterized as challenges that must be addressed. Recommendations are proposed.
\end{abstract}

Keywords: Caribbean, tourism planning, stakeholder perspectives, tourism assets, CTO

\section{Introduction}

\subsection{Global Significance of the Tourism Industry}

The tourism industry is recognized as a major development strategy for countries and regions worldwide. This industry is considered vital to tackling global economic challenges. In spite of the unpredictability of the global economy, the tourism industry has continued to grow, albeit, at different regional rates. Encompassing transportation, lodging, dining, leisure activities and services for travelers, the travel and tourism industry is one of the largest industries in the world and a major generator of jobs bringing significant social, cultural and economic, and benefits to the global economy.

This industry caters to travelers or tourists who are, as defined by World Tourism Organization (UNWTO, 1995), persons "traveling to and staying in places outside their usual environment for not more than one consecutive year for leisure, business and other purposes". The 1991 Manila Declaration on World Tourism defined tourism as an "activity essential to the life of nations because of its direct effects on the social, cultural, educational and economic sectors of national societies and on their international relations" (UNWTO, 1995). The industry's importance as a major social and economic development strategy was recognized during the Rio Earth Summit in1992, when the UN Conference on Environment and Development identified Travel and Tourism as a key economic sector which could positively contribute to sustainable development. The Summit led to the implementation of Agenda 21, an all-inclusive action plan adopted by governments to provide a global plan for sustainable development. The Travel and Tourism industry was first to launch an action plan based on Agenda 21. 
According to the World Tourism Organization (UNWTO, 2011) tourism is vital to tackling global economic challenges and in spite of the unpredictability of the global economy, international tourism is one of the few sectors that continues to grow. Worldwide, the number of international tourists grew from 435 million to 940 million at an average annual rate of about 3.4\% (Table 1) during 1990 through 2010 (UNWTO, 2011). Arrivals in the Americas, however, only grew by an annual average rate of $1.6 \%$. Central and South America experienced the largest rates with $4.4 \%$ and $6.4 \%$, respectively, while the Caribbean experienced an average growth rate of $1.7 \%$ between 2000 and 2010. UNWTO data shows that overall, international tourists arrivals in the Caribbean grew by approximately the same rate between 1990 and 1995 (22.8\%) and 1995 to 2000 (22.1\%). However, the Region experienced significant declines with growth rates of $9.9 \%$ between 2000 and 2005 and $6.9 \%$ during 2005 and 2010.

Table 1. International tourist arrivals by region and sub-regions, $1990-2010$

\begin{tabular}{|c|c|c|c|c|c|c|c|c|c|}
\hline \multirow[t]{2}{*}{ World/Region } & \multicolumn{5}{|c|}{$\begin{array}{l}\text { International Tourist Arrivals } \\
\text { (million) }\end{array}$} & \multirow{2}{*}{$\begin{array}{c}\begin{array}{c}\text { Market } \\
\text { share (\%) }\end{array} \\
2010^{*}\end{array}$} & \multicolumn{2}{|c|}{ Change (\%) } & \multirow{2}{*}{$\begin{array}{c}\begin{array}{c}\text { Average annua } \\
\text { growth (\%) }\end{array} \\
2000-2010\end{array}$} \\
\hline & 1990 & 1995 & 2000 & 2005 & $2010^{*}$ & & $09 / 08$ & $10 * / 09$ & \\
\hline World & 435 & 528 & 675 & 798 & 940 & 100 & -3.8 & 6.6 & 3.4 \\
\hline Americas & 92.8 & 109.0 & 128.2 & 133.3 & 149.8 & 15.9 & -4.9 & 6.4 & 1.6 \\
\hline North America & 71.7 & 80.7 & 91.5 & 89.9 & 98.2 & 10.5 & -5.7 & 6.6 & 0.7 \\
\hline Caribbean & 11.4 & 14.0 & 17.1 & 18.8 & 20.1 & 2.1 & -2.8 & 3.0 & 1.7 \\
\hline Central & 1.9 & 2.6 & 4.3 & 6.3 & 7.9 & 0.8 & -7.4 & 3.8 & 6.2 \\
\hline South America & 7.7 & 11.7 & 15.3 & 18.3 & 23.5 & 2.5 & -2.3 & 9.7 & 4.4 \\
\hline
\end{tabular}

Source: UNWTO, 2011.

* Estimates

It has been advanced that the Caribbean is highly reliant on tourism to support peoples' livelihoods, more than any other region in the world (Nurse, 2007). But globalization has left the island nations of the Caribbean with limited alternative economic options, and tourism has now emerged as the largest employer and the foremost foreign exchange earner in the Region. Nurse (2007) also claims that CTO members have one percent of the world's population but attract three percent of global tourism arrivals and expenditure each year. UNWTO (2011) estimated the Caribbean's market share at $2.1 \%$ in 2010. The Caribbean tourism industry exhibited sustainable levels of growth, amid the turbulence in the marketplace during 2011 (Smith, 2012). CTO also contends that recovery from the 2008/2009 global financial crisis and economic recession began in 2010 and is showing signs of continuing. Furthermore, the CTO estimates that overall the Caribbean received 23.8 million tourists in 2011, a 3.3\% increase from 2010. Nevertheless, the Organization acknowledges that there are signs that the Region is still vulnerable, as the data revealed uneven growth among the countries and revenue continuing to lag behind arrivals (Smith, 2012).

The contribution of tourism to socio-economic development is closely correlated with receipts and spending in the national economy. International tourism receipts by regions of the world including the Americas' sub-regions are presented in Table 2. Growth in international tourism revenues in 2010 was assessed at $4.7 \%$. This was measured in real terms, using local currencies at constant prices adjusting for fluctuation in exchange rates and inflation. UNWTO (2011) estimated that international tourism receipts reached US\$919 billion in 2010, up from US\$851 billion in the previous year, an increase of over $250 \%$ from 1990 . This shows that the recovery in international tourism receipts $(4.7 \%)$ lagged that of international arrivals $(6.6 \%)$. The same pattern is seen in the Caribbean with a growth of $3.0 \%$ in tourist arrivals between 2009 and 2010 and a $2.1 \%$ in international receipts during the same time period. UNWTO (2011) contends that this is characteristic of recovery periods when, after major shocks, arrivals tends to recover faster than revenues, competition is stronger and suppliers make concerted efforts to contain prices, and tourists also tending to travel closer to home and take short trips. In 2010, UNWTO (2011) also estimated that the Caribbean had higher receipts per arrival $(\$ 1,180)$ than the worldwide average $(\$ 980)$. 
Table 2. International tourism receipts by region, percent change, $2007-2010$

\begin{tabular}{|c|c|c|c|c|c|c|c|}
\hline \multirow[t]{3}{*}{ World/Region } & \multicolumn{3}{|c|}{ International Tourism Receipts } & \multirow[t]{2}{*}{ Share $(\%)$} & \multicolumn{3}{|c|}{ Receipts US\$ } \\
\hline & \multicolumn{3}{|c|}{ Local currencies, constant prices change (\%) } & & \multicolumn{2}{|c|}{ Billion } & \multirow{2}{*}{$\frac{\text { Per arrival }}{2010^{*}}$} \\
\hline & $08 / 07$ & $09 / 08$ & $10 * / 09$ & $2010^{*}$ & 2009 & $2010^{*}$ & \\
\hline World & 1.7 & -5.6 & 4.7 & 100 & 851 & 919 & 980 \\
\hline Americas & 4.9 & -9.9 & 5.0 & 19.8 & 166.2 & 182.2 & 1,220 \\
\hline North America & 6.9 & -12.4 & 6.2 & 14.3 & 119.2 & 131.2 & 1,340 \\
\hline Caribbean & -3.2 & -5.3 & 2.1 & 2.6 & 22.6 & 23.6 & 1,180 \\
\hline Central America & 0.3 & -3.4 & 4.1 & 0.7 & 6.1 & 6.8 & 850 \\
\hline South America & 3.1 & -0.3 & 1.2 & 2.2 & 18.3 & 20.6 & 880 \\
\hline
\end{tabular}

Source: UNWTO, 2011.

* Estimates

\subsection{Focus of Study}

Tourism is considered a significant driver of sustainable economic growth and development for the Caribbean region. Grandoit (2005) indicated that many development agencies in the international arena have promoted the tourism industry as a development tool for small countries like those in the Caribbean which have no "real" viable alternatives for economic development. However, although the Region has experienced relatively high levels of wealth creation and GDP per capita, at the same time the Region has had to contend with issues of high levels of poverty, rising food and fuel costs, weak governmental accountability, vulnerability to dangerous natural events and climate change, and poor overall economic diversification (UNDP, 2009). In addition, concern has been mounting about the negative impacts of the tourism industry particularly on cultural and natural resources. This research explores the perspectives of Caribbean tourism stakeholders to identify perceived strengths and assets of the Region and to assess challenges and opportunities faced by the Region's tourism industry. The primary questions addressed in this study were:

I. What are the Caribbean's primary tourism assets/strengths?

II. Which regional organization/agency/institution has had the greatest impact on or made the greatest contribution to the Region's tourism sector?

III. What are critical factors which hinder or negatively impact the development, growth and sustainability of the Region's tourism sector?

\subsection{Interest and Importance of Stakeholder Perception in Tourism Research}

Increasing attention has been given to residents' and stakeholders' perceptions of the impact of tourism and a significant number of studies have emerged focusing particularly on the perceptions and attitudes towards socio-cultural impacts (Wall \& Mathieson, 2006). Existing literature suggests several reasons for this. Evaluation of residents' perceptions could be a valuable component identifying and measuring tourism impact (Getz, 1994). In fact, the majority of tourism impact studies have been conducted through measuring residents' attitudes and the effects that are perceived by community residents' (Zhang et al., 2006). In addition to identifying residents' perception for improvement of quality of life, identifying residents' attitudes is important in determining level of public backing for tourism expansion as well as the available opportunities, or in evaluation of perceptions of problems that should be solved (Williams \& Lawson, 2001). By determining the attitudes of local populations, programs can be designed and implemented to minimize conflict between tourists and residents (Lankford \& Howard, 1994) and therefore to pursue the goal of sustainable tourism.

The body of literature examining local residents' attitudes towards tourism reflects a wide variety of conclusions. The general consensus is that there are numerous factors that may influence residents' attitudes and also residents hold diverse opinions about tourism development (Mason \& Cheyne, 2000). Even though some literature has observed inconsistent relationships between a variant of socio-economic factors influencing residents' perception (Milman \& Pizam, 1988), Cordero (2008) supports Harrill (2004) who claims differently and suggests that socio-demographic variables are influential in shaping residents' perceptions towards tourism. These variables include gender, age, birthplace and level of community attachment, ethnicity, education level and length of residence. In addition, other variables such as economic and tourism development, economic dependency, tourist-resident contact, proximity to resorts, level of knowledge about tourism and involvement of 
residents in tourism decision making have also been identified as influential in residents' perceptions towards tourism (Cordero, 2008).

Some theoretical foundations have been suggested as the basis for conceptual development in residents' attitudes towards tourism (Cordero, 2008). The Social Exchange Theory is one such theory. Within a tourism framework, the Social Exchange Theory postulates that an individual's attitude towards tourism is influenced by his/her evaluation of consequential outcomes to the community (Andereck et al., 2005) although not always fully empirically supported. The Social Representations Theory is another theoretical framework that has been proposed for the understanding of community attitudes towards tourism (Fredline \& Faulkner, 2000). This specifically focuses on understanding everyday knowledge and how this knowledge is used to understand the world in which individuals live and therefore to guide their actions and decisions.

\section{Materials and Methods}

\subsection{The CTO Region}

CTO member countries span the wider Caribbean region from the Bahamas in the north, Mexico (Cancun/Cozumel) and Belize to the west, Barbados to the east through Venezuela and Guyana to the south (Figure 1). This Region, consisting of the islands, territories and mainland countries whose shores are washed by the Caribbean Sea, takes its name from the Carib Indians, an ethnic group present in the area at the time of European contact. Silva (2002) identifies seven CTO Caribbean sub-regions (Table 3). Overall, the CTO Caribbean countries grew by 4.2\% between 2009 and 2010 with the Spanish Caribbean (Cancun, Cozumel, Cuba, Dominican Republic, and Puerto Rico) leading the way with a growth of 5.1\% (Griffith, 2011). All of the other subgroupings showed positive but modest growth over the year. The Organization of Eastern Caribbean States (OECS) region, for example, grew by $2.9 \%$ and other Caribbean Common Market (CARICOM) countries grew by $3.8 \%$. The Dutch Caribbean, however, did not grow and in fact, experienced a $0.1 \%$ decline in the total number of arrivals between 2009 and 2010 (Griffith, 2011).

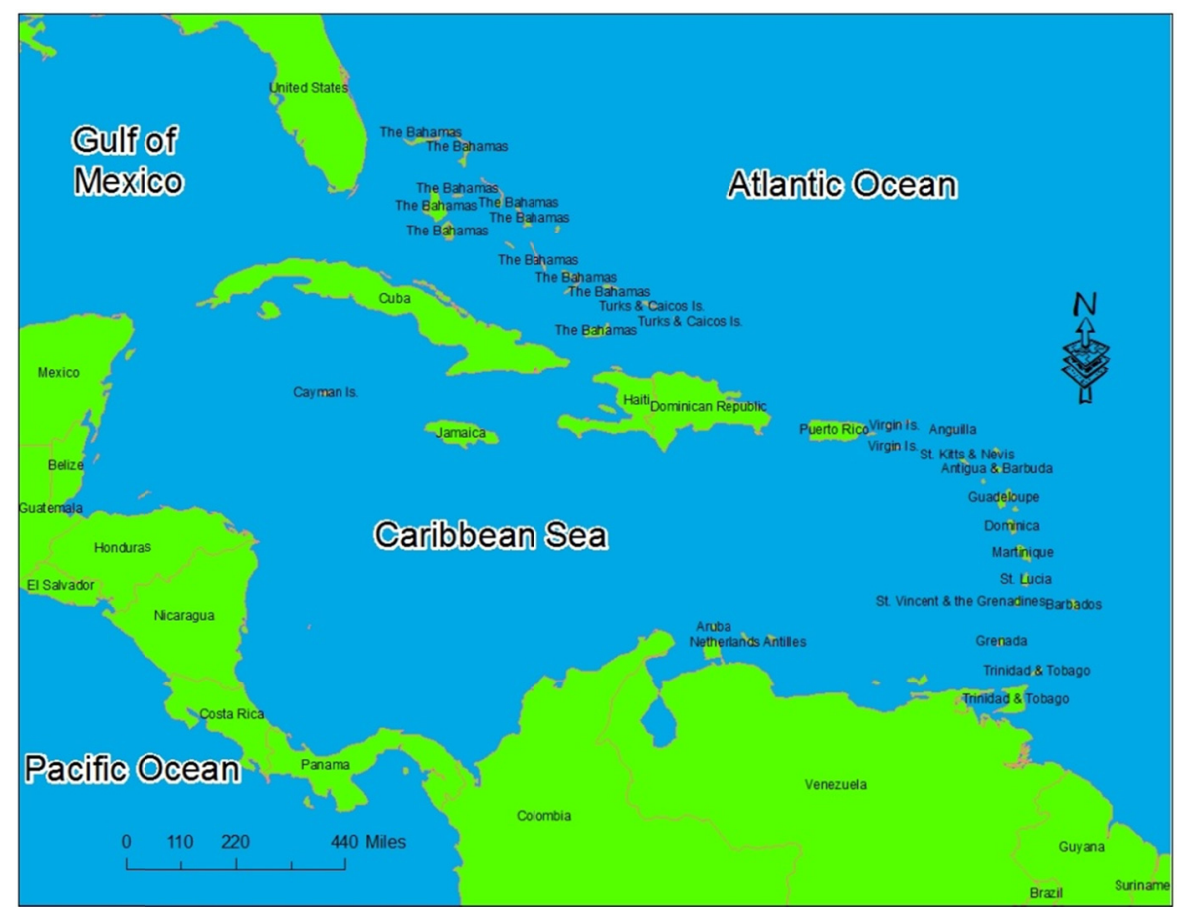

Figure 1. Map of the Caribbean Tourism Organization's member countries (adapted from: Silva, 2002) 
Table 3. CTO Caribbean sub-regions

\begin{tabular}{cc}
\hline OECS Countries & Dutch West Indies \\
\hline Anguilla & Aruba \\
Antigua \& Barbuda* & Bonaire \\
British Virgin Islands & Curacao \\
Dominica* & Saba \\
Grenada $*$ & St. Eustatius \\
Montserrat* & St. Marteen \\
St. Kitts and Nevis* & French West Indies \\
St. Lucia $*$ & Guadeloupe \\
St Vincent and the & Martinique \\
Grenadines* & \\
\hline Other CARICOM & Hispanic Caribbean \\
\hline The Bahamas & Cuba \\
Barbados & Dominican Republic \\
Belize & Mexico: Cancun /Cozumel \\
Guyana & Venezuela \\
Jamaica & \\
Trinidad and Tobago & \\
Haiti & US Virgin Islands \\
Suriname & \\
\hline Other Commonwealth & \\
\hline Bermuda & \\
\hline Cayman Islands & \\
\hline CARICOM Sub-grouping & \\
\hline and Caicos Islands & \\
\hline
\end{tabular}

* Members of the CARICOM Sub-grouping.

Source: Silva, 2002.

UNDP (2009) concludes that the situation within the Caribbean can be characterized as a 'development paradox' due to the fact that, while many of the countries have achieved and/or maintained relatively high levels of GDP per capita and economic growth, financial prosperity, political stability and infrastructure development, there remains substantial under-employment, poverty, gender and social inequities and weak institutional capacities. CTO (2007) contends that tourism in the Caribbean is dependent on a mix of man-made, natural, cultural, and social assets. These include favorable climate, the tourism plant, infrastructure, natural amenities, access to clean and sufficient water supplies, access to readily available and relatively inexpensive supply of energy, financial services, healthy environments, sufficient supplies of food, and social accord. Nevertheless, increasing costs of fuel and food, weak public accountability, modest distributive societal mechanisms, poor overall economic diversification, and susceptibility to extreme climatic events point to the many pressing and sensitive trials that face the Region in attempting to balance success and threats (UNDP, 2009).

At both the regional and sub-regional levels, the Caribbean is undergoing major economic change due to globalization and the push towards competitive and open markets and economic integration. Driven by CARICOM's Caribbean Single Market and Economy initiative, this process pursues the transformation of the Region into a more sustainable, globally-oriented standard of development linked to world markets (UNDP, 2009). While these changes have benefited the island economies, they have also created issues related to the impartial distribution of resources and the need to synchronize political and economic management systems. 


\subsection{Methodology}

In an attempt to identify, measure, and analyze the strengths, challenges and opportunities critical to the Region's tourism sector, perspectives were sought from participants who attended the Caribbean Tourism Organization's Sustainable Tourism Conference in Barbados in May 2010. Conference participants represented the range of regional tourism stakeholders (elected officials, professionals, technocrats, administrators, tour operators, hoteliers, academia, and other service providers). The research strategy involved the use of a questionnaire administered to a convenience sample of Conference participants. The questionnaire was divided into three parts. Part I consisted of four questions which sought to assess the demographics, employment status and affiliation of respondents. Part II, comprised of four questions, focused on respondents' perception of and satisfaction with the level of growth and development realized in the Tourism Sector as well as the challenges/options and future outlook for the Sector. The focus of Part III, made-up of a single question, was on regional tourism-related organizations whereas Part IV, consisting of three questions, examined participation in the Conference.

Although the results of analysis based a convenience sample are not usually used to assess the opinions of the entire study population, the researchers felt this methodology was appropriate in this particular example, given the exploratory nature of the study. The intent, however, was to gain input from the entire population of Conference participants. In this regard, through several conference announcements, all participants were invited to and had ample opportunities to participate in the study.

Twenty (27\%) of the estimated 100 participants at the Conference completed questionnaires. Several published studies have reported similar or smaller response rates. For example, Nordquist (2006) reported a $29 \%$ response rate, while a $15 \%$ response rate was reported by Reiss, Schoenig and Wright (2006). Thus, given the exploratory nature of this study the small number of respondents was considered acceptable. Any follow-up studies, however, should seek to ensure a higher response rate to facilitate hypothesis testing and to enable more robust analysis.

SPSS (Statistical Package for the Social Sciences) was used for data analysis. This software is among the most widely used programs for statistical analysis in social science. Descriptive statistics, cross tabulations, correlation analyses and a cluster analysis were performed on the data to answer the research questions.

\section{Results and Discussions}

\subsection{Demographic Profile of Respondents}

A total of 27 persons responded to the questionnaire of which $26 \%$ were males, $59 \%$ females, and $15 \%$ did not identify their gender. Forty-five percent of the respondents were between 41 to 50 years old. Furthermore, the results show that $3.7 \%$ of the respondents were in the 20 to 25 age range and a similar percentage in the 36 to 40 age category. The highest number (48\%) of the respondents was of Black/Afro-West Indian decent whereas $7.4 \%$ of the respondents identified themselves as members of the Region's Carib Indian/Indigenous population.

A majority of the respondents, (56\%), represented island states rather than regional or international organizations. The respondents were predominantly long term residents who were highly educated. Forty-eight percent lived in their respective country of residence for 10 years or more, $33 \%$ had completed a four year college degree while $44 \%$ had masters' degrees. The respondents represented diverse sectors - the private sector was represented by $26 \%$, NGOs by $11 \%$, and governmental agencies by $37 \%$. Thirty percent of respondents have been involved in the tourism industry for 6 to 10 years. Tables 4 and 5 summarize of the respondents' demographic and social characteristics.

The demographic characteristics of the sample as illustrated through the analyses are reflective of the overall demographics of the population of Caribbean tourism stakeholders. The low participation of persons in the 20 to 25 age range in the study is a reflection of limited youth involvement in the Region's tourism sector, particularly at the management or agency representative level. The high percentage of Blacks/Afro-West Indians in the sample was not surprising considering that Region's population is predominantly of this particular ethnic group. It was interesting to note, however, that $7.4 \%$ of the respondents identified themselves as members of the Region's Carib Indian/Indigenous population, considering that few islands among the CTO member states have Carib Indian/Indigenous populations. Participants from the Wider Caribbean mainland countries may have contributed to this somewhat surprising result. 
Table 4. Demographic characteristics of respondents: gender, ethnicity, residence and age

\begin{tabular}{|c|c|c|c|c|c|c|c|}
\hline \multicolumn{2}{|c|}{ Gender } & \multicolumn{2}{|l|}{ Ethnicity } & \multicolumn{2}{|c|}{ Length of Residence (Yrs.) } & \multicolumn{2}{|c|}{ Age Group (Yrs.) } \\
\hline Category & $\%$ & Category & $\%$ & Category & $\%$ & Category & $\%$ \\
\hline No Response & 14.8 & No Response & 7.4 & No Response & 3.7 & No Response & 7.4 \\
\hline Male & 25.9 & $\begin{array}{l}\text { Black/Afro-West } \\
\text { Indian }\end{array}$ & 48.1 & $<1$ & 11.1 & $20-25$ & 3.7 \\
\hline \multirow[t]{3}{*}{ Female } & 59.3 & $\begin{array}{c}\text { Carib } \\
\text { Indian/Indigenou } \\
\text { s Population }\end{array}$ & 7.4 & $1-5$ & 14.8 & $26-30$ & 11.1 \\
\hline & & $\begin{array}{c}\text { White/ } \\
\text { Caucasian }\end{array}$ & 18.5 & $6-10$ & 22.2 & $31-35$ & 11.1 \\
\hline & & Mixed & 18.5 & $11-20$ & 18.5 & $36-40$ & 3.7 \\
\hline & & & & $21-30$ & 3.7 & $41-50$ & 44.4 \\
\hline & & & & $>30$ & 25.9 & $51-60$ & 7.4 \\
\hline & & & & & & $>60$ & 11.1 \\
\hline
\end{tabular}

Table 5. Years of respondents' tourism involvement and agencies represented

\begin{tabular}{cccc}
\hline \multicolumn{2}{l}{ Involvement in Sector (Yrs.) } & \multicolumn{2}{c}{ Agency Represented } \\
\hline Category & Percent & Category & Percent \\
$<1$ & 7.4 & No Response & 3.7 \\
$1-5$ & 14.8 & Elected Official & 0.0 \\
$6-10$ & 29.6 & Appointed Official & 3.7 \\
$11-15$ & 7.4 & Government Employee & 37.0 \\
$16-20$ & 11.1 & Educator & 11.1 \\
$21-25$ & 11.1 & Private Sector & 25.9 \\
$26-30$ & 7.4 & NGO & 11.1 \\
$>31$ & 11.1 & Other & 7.4 \\
\hline
\end{tabular}

\subsection{Regional Tourism Assets/Strengths}

Although tourism has become a very effective approach for communities to expand their social, economic, and environmental prospects, it is important that tourism activities are viable and in line with the community's vision. Identification of assets, weaknesses, and opportunities would enable the Region to identify core elements for re-branding, formulating a roadmap detailing the strategic direction for product development and enhancing the sector's competitiveness, and ultimately improve the tourists' experience.

Travelers' changing demographic and socio-economic conditions have implications for the products they prefer and their motivations for travel. Therefore, it is imperative for the Region to develop a sound understanding of its assets and strengths to facilitate appropriate marketing and promotion efforts to the new and discriminating traveler. In addition, knowledge of the strengths, weaknesses, opportunities, and threats to tourism in the Region will enable better long term planning, the generation of new investments, increased targeted marketing and promotion efforts and ultimately an improved quality product. Asset mapping helps to identify opportunities that seek to use and build on these existing resources and is an important initial step in projects that are designed towards community transformation.

Respondents were asked to identify what they considered the most important community assets for tourism. Approximately thirty-three percent (33.3\%) rated culture as the primary asset whereas almost $30 \%$ rated both the Region's friendly people and favorable weather as the two second most important assets (Figure 2). However, among the top five, participants ranked people highest $(81.5 \%)$, followed by weather $(74.1 \%)$, beaches and water 
bodies (70.4\%) and cuisine (59.3\%) (Figure 3). Even though 33.3\% ranked culture as number one, only $48.1 \%$ of the respondents considered culture among the top five of the Region's primary assets and strengths.

Several studies have discussed the notion of community resources which can be used as a base for community development. Identifying and mobilizing community assets can help to enable community residents to enrich their lives. Improvement endeavors are more effective and last longer when members of the community dedicate their time, collective wisdom, and talents to help secure changes they desire. In tourism planning it is important to recognize the kinds of resources that are available in a given region and how individuals and agencies can work together with the community to marshal these assets to help the community achieve its goals.

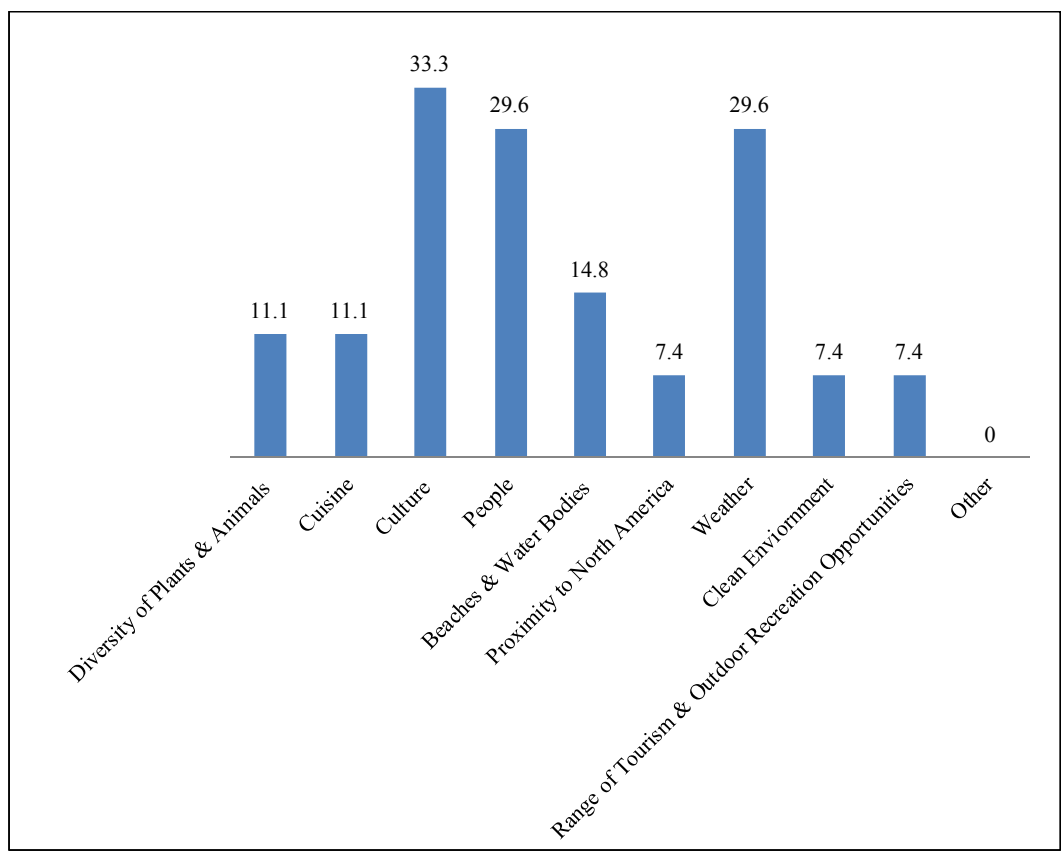

Figure 2. Respondents' ranking of primary tourism assets

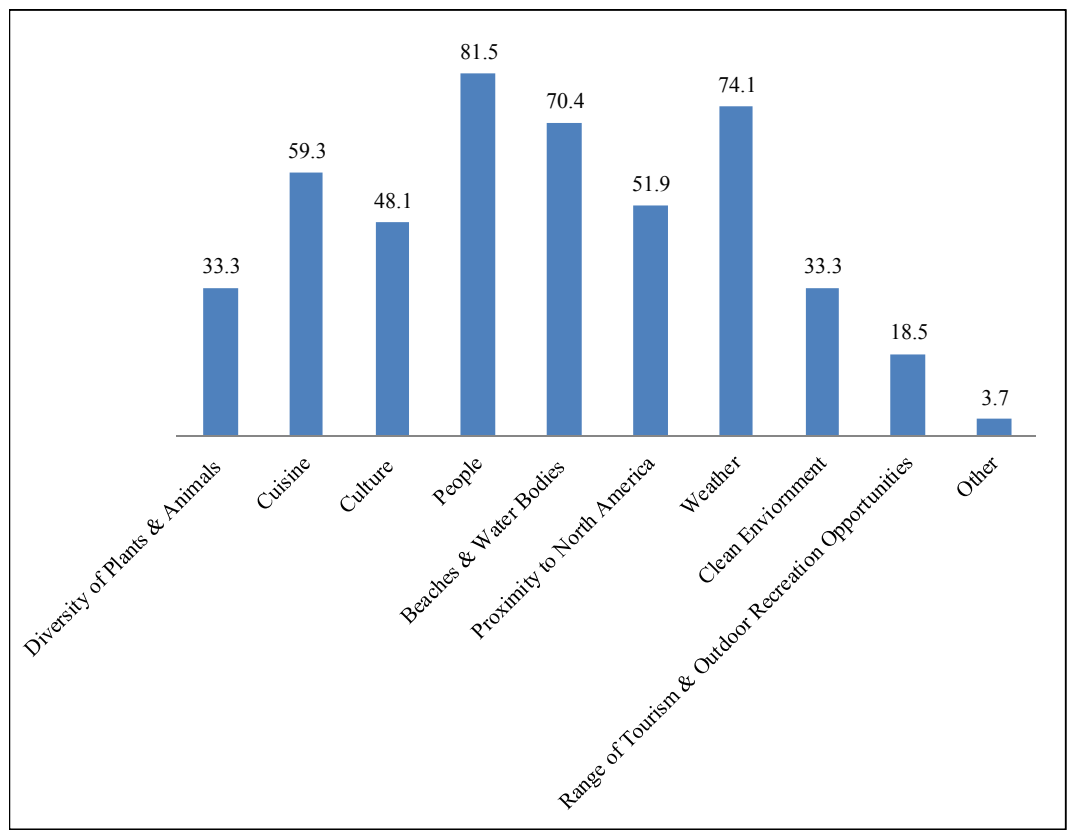

Figure 3. Respondents' ranking top five tourism assets 
Ashley et al. (2000) noted that tourism development can change local people's access to resources and to related livelihood opportunities. On one side, it can build or enhance physical assets by generating funds for investment in education, health, and other sub-sectors, support infrastructure, encourage development of social capital, strengthen the sustainable management of natural resources and create a need for improved services. On the other side, tourism can reduce local access to natural resources, particularly if local people are excluded from tourism areas. It can also erode social capital if conflict over tourism undermines community and mutual relations and draw heavily upon and often over burden local physical infrastructure.

Location and infrastructure are important for economic development, but inadequate for sustainable tourism. Sustainable projects are often related to the involvement of residents. Ashley et al. (2000) contend that benefits from tourism to the local population (particularly the poor) depend on whether and how persons participate in the industry. They indicate that several factors ranging from the local (assets, gender, livelihood strategies) to the policy environment (tenure, regulations) and commercial context (market segments) influence local peoples' involvement.

Respondents also ranked culture and physical assets such as beaches and cuisine as being very important priorities to the Region's tourism industry. Traditional studies of the urban environment generally considered culture as subordinate to the economy in terms of development. Post-industrial and globalizing trends, however, are intensely elevating the significance of culture with cultural activities increasingly being recognized as critical to urban economic robustness.

\subsection{Critical Factors Impacting the Tourism Sector}

Respondents showed strong consensus in their concern about growth management, active community and stakeholder involvement and integrated tourism development in the Region (Table 6). The majority (51.9\%) strongly disagreed that there was active community and stakeholder involvement in tourism in the Region. Half of the respondents felt that hotels did meet industry standards, although $22 \%$ expressed no opinion. The majority $(59.3 \%)$ felt that the Region was unsuccessful in managing growth and $37 \%$ felt that the current legal framework does not adequately address crimes against tourists. Slightly more than a fourth $(25.9 \%)$ of the respondents strongly felt that youth involvement in the industry was not actively pursued.

Approximately one third (33.3\%) of the respondents felt that there was an absence of clear political and policy directions with regards to tourism in the Region. Concern was expressed for the loss of biodiversity and natural resources $(22.2 \%)$, a lack of integrated zoning and land use planning $(18.5 \%)$, and availability and access to capital particularly for new plants (14.8\%). Small percentages of the respondents felt that there was a monopoly of travel services to the Caribbean (11.1\%), inadequate marketing and promotion of destination $(7.4 \%)$ and tourism support services (3.7\%). Disquiet was also expressed about visitor security and safety (7.4\%).

Figure 4 compares the various concerns and issues expressed by the participants.

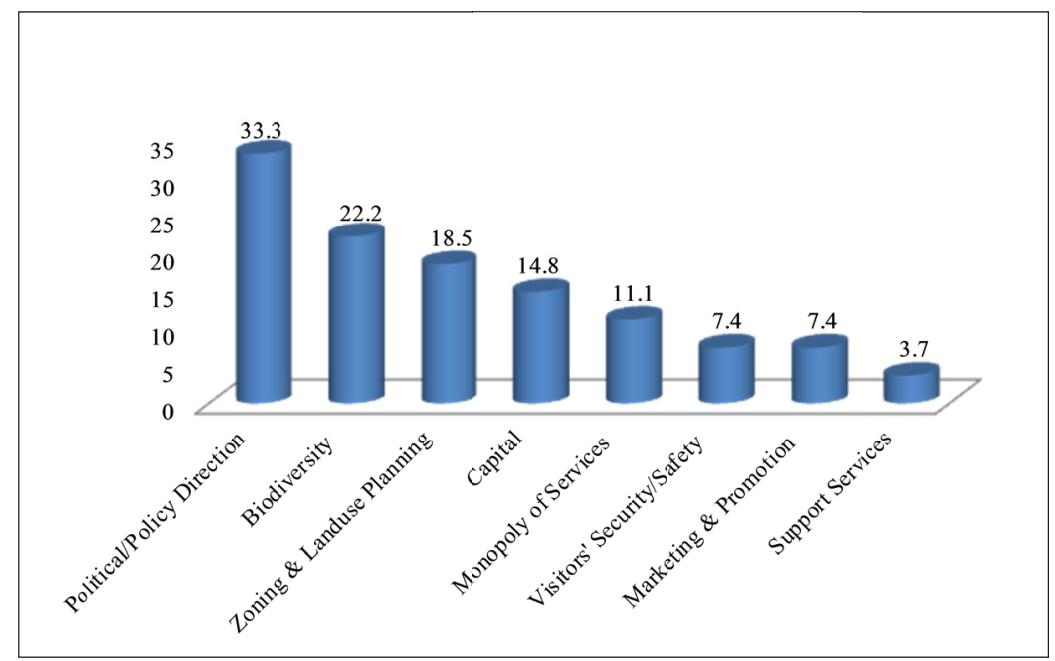

Figure 4. Rating of issues facing the Caribbean Region's tourism sector 
Table 6. Respondents' level of agreement with regional issues, by percentage

\begin{tabular}{|c|c|c|c|c|c|c|}
\hline $\begin{array}{l}\text { Level of } \\
\text { agreement }\end{array}$ & $\begin{array}{l}\text { Poor growth } \\
\text { management }\end{array}$ & $\begin{array}{l}\text { Inadequate } \\
\text { stakeholder } \\
\text { involvement }\end{array}$ & $\begin{array}{c}\text { Youth } \\
\text { involvement } \\
\text { actively pursued }\end{array}$ & $\begin{array}{c}\text { New hotels do } \\
\text { not meet } \\
\text { industry } \\
\text { standards }\end{array}$ & $\begin{array}{l}\text { Weak legal } \\
\text { framework for } \\
\text { addressing } \\
\text { crime }\end{array}$ & $\begin{array}{c}\text { Integrated } \\
\text { tourism } \\
\text { development not } \\
\text { promoted }\end{array}$ \\
\hline $\begin{array}{l}\text { Strongly } \\
\text { Agree }\end{array}$ & 11.1 & 7.4 & 7.4 & 14.8 & 0.0 & 14.8 \\
\hline Agree & 59.3 & 29.6 & 51.9 & 3.7 & 25.9 & 48.1 \\
\hline Disagree & 22.2 & 7.4 & 3.7 & 51.9 & 14.8 & 3.7 \\
\hline $\begin{array}{l}\text { Strongly } \\
\text { Disagree }\end{array}$ & 0.0 & 51.9 & 25.9 & 0.0 & 37.0 & 14.8 \\
\hline No opinion & 0.0 & 0.0 & 7.4 & 22.2 & 11.1 & 11.1 \\
\hline
\end{tabular}

Pearson product-moment correlation analysis of selected issues/variables reveals a number of statistically significant relationships. For example, 'deterioration of existing infrastructure' and the 'absence of a clear political and policy direction' produced an $r=0.513$ at $\alpha=0.01$ whereas correlation between 'deterioration of existing infrastructure' and 'inadequate tourism support services' resulted in $r=0.511$ at $\alpha=0.01$. Similar relationships also exist between 'a lack of integrated zoning and land use planning' and 'loss of biodiversity and natural resources' $(r=0.402, \alpha=0.05)$ and the 'lack of capital for new tourism plants' and 'inadequate marketing and promotion of destinations' $(r=0.415, \alpha=0.05)$ (Table 7). The results indicate concern for a clear direction from the political directorate to plan, develop and manage tourism which, if not done properly, can contribute to further deterioration of existing infrastructure.

Table 7. Pearson product-moment correlations among key issues facing the Caribbean region

\begin{tabular}{lccc}
\hline \multicolumn{1}{c}{ Issue } & $\begin{array}{c}\text { Deterioration of existing } \\
\text { infrastructure }\end{array}$ & $\begin{array}{c}\text { Lack of integrated } \\
\text { zoning and land-use } \\
\text { planning }\end{array}$ & $\begin{array}{c}\text { Lack of and/or cost of } \\
\text { capital for new plant }\end{array}$ \\
\hline $\begin{array}{l}\text { Absence of clear political and } \\
\text { policy direction }\end{array}$ & $0.513(* *)$ & 0.173 & 0.201 \\
$\begin{array}{l}\text { Inadequate tourism and } \\
\text { support services }\end{array}$ & $0.511\left(^{* *}\right)$ & 0.109 & 0.109 \\
$\begin{array}{l}\text { Loss of biodiversity and } \\
\text { natural resources } \\
\text { Inadequate marketing and } \\
\text { promotion of destination }\end{array}$ & 0.230 & $0.402\left(^{*}\right)$ & 0.198 \\
\hline
\end{tabular}

** Correlation is significant at the 0.01 level (2-tailed).

* Correlation is significant at the 0.05 level (2-tailed).

Overall, $62.9 \%$ of the respondents either agreed and/or strongly agreed that the impact of regional tourism was positive (Figure 5). Nurse (2007) supports this finding, contending that regional tourism creates jobs and wealth and has great capacity to contribute to the sustainable development efforts in the Region. It is also one of the few likely possibilities for development and there is a strong prospect that the industry will continue to grow. 


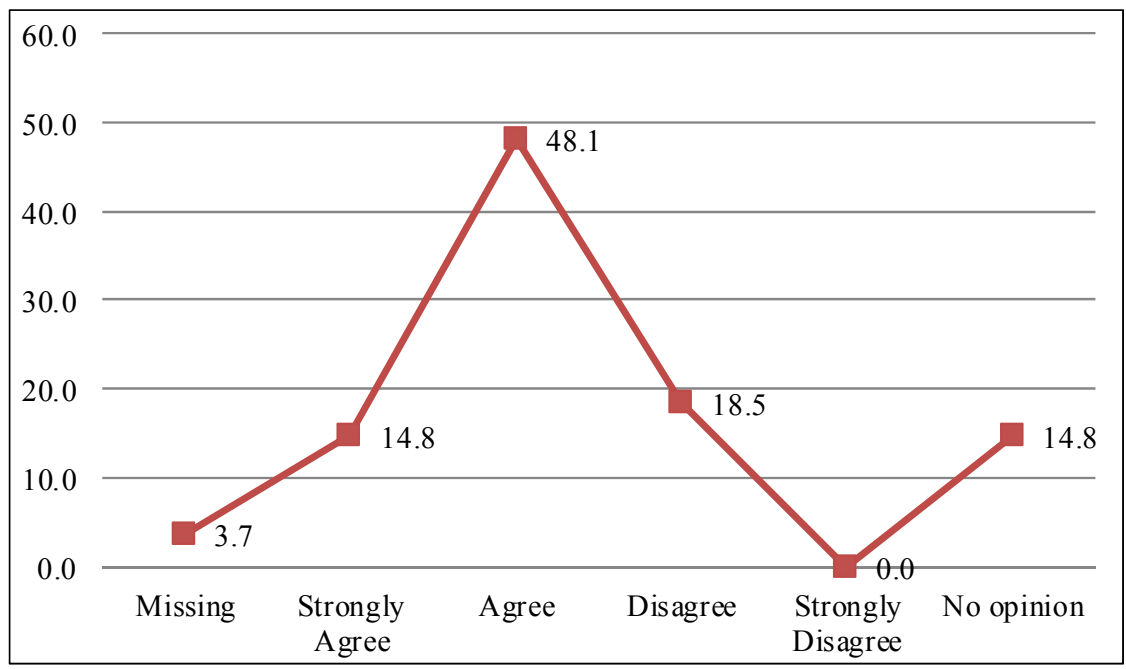

Figure 5. Respondents' positive rating of the overall impact of regional tourism

Although respondents considered the tourism industry's impact as being overall positive the industry has some inherent weaknesses which can negatively impact the Region. Grandoit (2005) illustrate that the island economies are export-oriented; resulting in these economies being highly dependent on external consumers and that marketing and consumption of the tourism product is mainly based on the experiences and desires of the tourist. Harrill (2004) contends that this industry is becoming an important element of economic development strategies world-wide. Furthermore, he states that planners who have conventionally considered industrial development as the only viable mode of economic development are now considering tourism a feasible option as the traditional businesses relocate because of lower labor and resource costs. Grandoit (2005) also addresses the issue of sustainability in small island economies. He notes that if tourism's use as a development tool is to be continued, policymakers must address the environmental vulnerabilities of these islands and pursue viable policies that address the driving forces and pressures sustained by these countries, if sustainable development is one of the Region's goals.

A cluster analysis was run on 27 cases, each responding to items on demographics (gender, age, years of involvement), on their attitudes to issues facing the tourism industry. A hierarchical cluster analysis using Ward's method produced three clusters. Eleven respondents were classified in cluster 1, eight in cluster 2 and eight in cluster 3. Cross tabulations between the nominal variables (gender, age and years of involvement) and the cluster variables indicate that cluster 1 was composed of all females, $64 \%$ of whom were 41 years and older and $91 \%$ of whom were involved in the tourism industry for 6 years and over. Cluster 2 was predominantly males, $50 \%$ of who were over 60 years of age and $75 \%$ were involved over 6 years in the industry. Cluster 3 was comprised equally of males and females, $50 \%$ of whom were under 35 years old and $83 \%$ were involved 6 years and more in the tourism industry. A one-way ANOVA was run to determine which classifying variables were significantly different between groups. The between group means are significant only for four of the ten issues (Absence of Clear Political \& Policy Direction, Monopoly of Travel Services to the Caribbean, Lack of Integrated Zoning \& Land use Planning, and Lack of and/or Cost of Capital for New Plant) indicating that these variables reliable distinguish between the three clusters.

\subsection{Organizations Critical to Regional Tourism Development}

Participants were asked their opinions about the contributions of a number of public and private sector agencies and non-governmental organizations to the development of tourism in the Caribbean. Results are captured in Figure 6. Seventy percent of the respondents rated the CTO and public sector tourism agencies in respondents' countries of residence as the organizations which make the most important contribution to regional tourism.

CTO, recognized as a major regional tourism body, provides a forum for the public and private sectors interested in developing, improving and promoting the Caribbean's tourism product and services. Comprised of over 32 member countries and allied members from the private sector (Silva, 2002), CTO's mission is to provide, to and through its members, the services and information needed for the development of sustainable tourism for the economic and social benefit of the Caribbean people. CTO provides a forum for discussion with governments and policy makers regarding issues that are critical to the overall health of the industry and allows for decisions 
to be taken at the highest levels. The Organization also provides dedicated support and technical advice to members in the areas of marketing, human resource development, research, information management and sustainable development. Acknowledging the need for coordination, CTO works in collaboration with several regional agencies such as the Association of Caribbean States (ACS), Regional Coordination Unit of UNEP, Caribbean Alliance for Sustainable Tourism (CAST), Pan American Health Organization (PAHO), and Natural Resources Management Unit of the Organization of Eastern Caribbean States (OECS/NRMU).

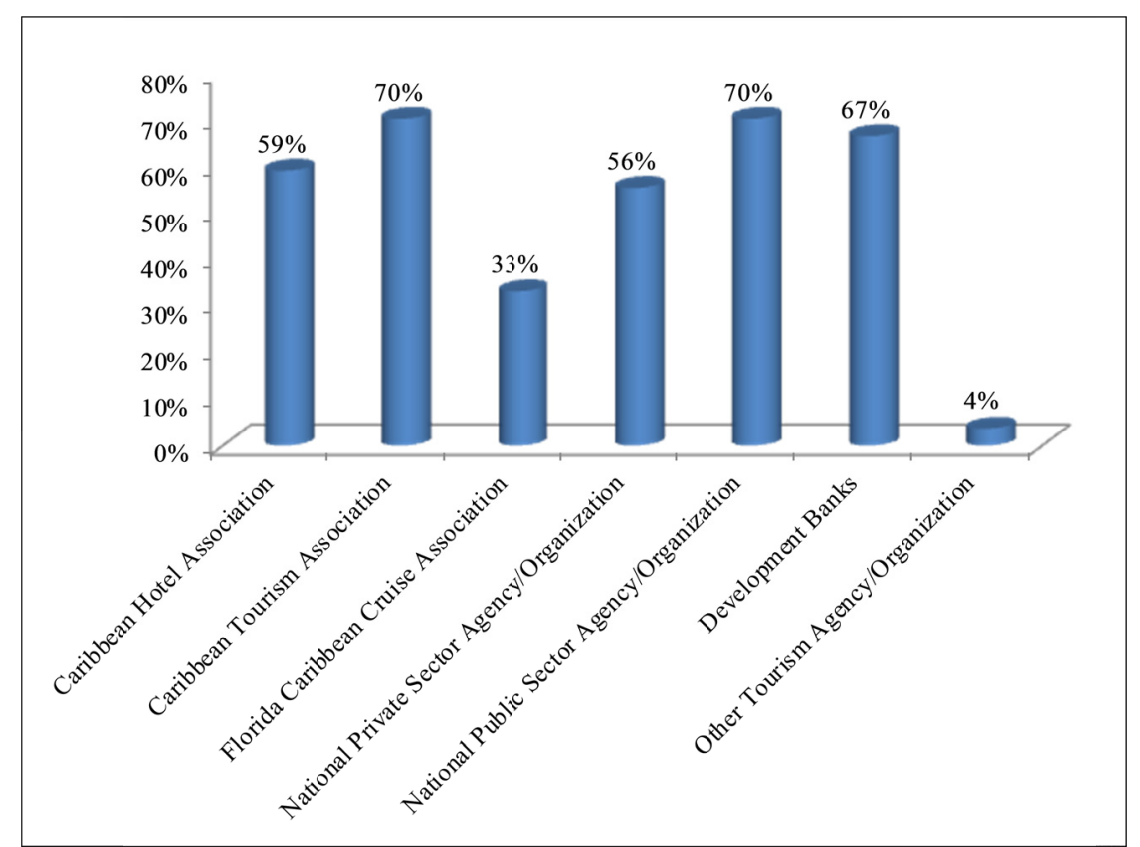

Figure 6. Organizations critical to the development/management of the Caribbean's tourism sector

National public sector tourism agencies (i.e. ministries of tourism and statutory tourism agencies) also ranked the highest in terms of contribution to tourism development. Ministries of Tourism in the Caribbean are usually given the responsibilities of creating tourism policy, coordinating the execution of supporting tourism strategies, and creating sector strategic plans. Tourism boards/authorities are usually public agencies whose main assignments are to promote the respective destinations and develop public awareness and education programs. These agencies, which usually work in conjunction with the Ministries of Tourism, also collect and analyze industry data to support decision making and sustainable marketing and promotion strategies.

Respondents also felt that development banks positively contribute to regional tourism development. Development banks exist in many of the countries in the Region. They are often wholly owned by the Government but operate as semi-autonomous and independent organizations guided by a Board of Directors. These banks usually fall under the direct responsibility of the Minister of Finance. The purpose of these banks is usually to provide medium and long term loans for the productive sector including agricultural, industrial and tourism development projects or ventures. The Caribbean Hotel and Tourism Association (CHTA), representing the private sector of the tourism industry in the Caribbean, was also deemed as an important contributor to tourism development. CHTA represents the various national hotel associations in the Region and emphasizes marketing, product development, tourism, sustainability, and social responsibility.

The 2011 Handbook on Tourism Product Development by the World Tourism Organization and the European Travel Commission notes that government's role in tourism product development is the identification and distribution of information about prospects, planning use of selected tourism development areas, and enabling their realization (UNWTO/ETC, 2011). Government's role, they claim, also includes the provision of direct investment and financial support in the form of grants, aid, and incentives. The Handbook asserts that local level administrations play a vital role in bringing tourism product development strategies to realization and require reliable, current information about the changing demands of tourists.

Fifty-six percent of the respondents acknowledged the importance of the private sector. According to UNDP (2009), the private sector has been deemed extremely important to drive investment, economic growth and 
sustainable development. However, resources are inadequate in some sectors and in most countries, and mechanisms for dialogue between government and offshore companies and investors are not fully developed. In addition, there is sometimes a lack of fruitful dialogue between government and the private sector on impacts and standards (UNDP 2009). Mather and Todd (1993) conclude that tourism in the Caribbean is both a vital economic activity and also one in which the Region should at least be able to maintain its market share. In order to achieve this, however, it will be necessary for the public and private sectors to work much more closely together and for the Region to adhere to the accepted norms with regard to cooperation and coordination.

Efficient partnerships can result in integrating travel and tourism policy into broader government regulations and incentives for the industry. Public/private partnerships can also assist in planning and developing infrastructure with a long term view and develop indicators and impact evaluation tools to permit effective local management and suitable development. Regional coordination can lead to consistency in approaches to tourism product development, coordination of destination management, identification and development of specialized tourism attractions, natural and cultural heritage conservation, and data collection. The private sector can pledge to place sustainable development issues at the center of its management agenda and provide innovative processes and application through new technologies.

\section{Summary and Conclusion}

The tourism industry in the Caribbean is at a cross-road. The findings of this study indicate that the Region's major asset is its human capital. Human capital, a key component of community capital, has an important positive impact on economic development. The socio-economic advantages and benefits of tourism to the Region are largely dependent upon how the local population participates in the industry.

Respondents felt that the locals are not actively involved in the Region's tourism industry. Although human capital was identified as the Region's major tourism asset, participants felt that the tourism strategy has not been sufficiently aligned towards local community improvement. This may be due in part to the fact that much of the Caribbean's present tourism products and services are principally administered by profit driven private enterprises including international hotel chains, airline companies and tour operators. Another possible explanation is the absence of an integrated national or regional approach to tourism development. This points to the need for a carefully crafted regional approach to engage the locals at all levels of the industry including the development of a policy framework, funding training programs, mentorships and succession planning strategies. The continued survival and long term viability of the Region's tourism sector hinges, to a large degree, on the extent to which the Region's people understands the critical importance of the sector to the Region's socio-economic survival as well as to their future well-being. In addition, CTO (n.d) stresses the importance of community-based tourism and contends that the resources of some local communities have been exploited with the locals receiving minimal benefits. CTO emphasizes the need for active involvement and enabling of local people to reap sufficient benefits from the tourism industry.

Several initiatives have been developed to promote and bring local entrepreneurs into the Caribbean's tourism supply chain. Yet much more must be done to ensure the tourism industry makes a more meaningful contribution to poverty alleviation and sustainable development through developing linkages with other productive formal and informal sectors.

Participants considered the cultural heritage of the local population as one of the Region's major strengths. According to the publication, Competing with the Best: Good Practices in Community-Based Tourism in the Caribbean, "...communities are the carriers of culture and lifeboats to the future" (CTO, n.d.). This suggests that tourism activities in the Caribbean should seek to have a community focus whenever feasible. CTO (n.d) also advocates that tourism should be "of, by, for and with the full consent and embrace of the community and defining it in any other way would marginalize efforts that should be at the heart of sustainable development". CTO proposes an operational definition of sustainable community-based tourism as: "A collaborative approach to tourism in which community members exercise control through active participation in appraisal, development, management and/or ownership, in whole or in part, of enterprises that delivers net socio-economic benefits to community members, conserves natural and cultural resources and adds value to the experiences of local and foreign visitors. This encompasses both tourism activities in a community and goods and services supplied to the tourism industry by one or more community members". Sub-sectors such as ecotourism/nature tourism and cultural tourism have good potential for the Region. These can enable stronger stakeholder involvement and local participation.

An important concern for respondents was the absence of a clear political and policy direction. The relationships between tourism and other sectors of the Region's economy are often poorly understood and often not evident. 
Poor coordination, lack of collaboration, and 'turf protection' have frequently surface between national agencies with mandates for the management of the country's tourism resources. The results have been duplication of efforts, poor resource management, and reduced efficiency and effectiveness, among others. Individually, Caribbean governments have often expressed commitments to the growth and development of the tourism industry. However, at the regional level the coordination of these proposed policy actions has been limited. The need for stronger regional commitment is therefore obvious. The regional focus is important because unwillingness by neighboring countries to manage shared resources such as the Caribbean Sea and the reluctance to address common threats such as airlift can undermine local accomplishments and render them ineffective.

Concerns expressed by the study's participants about the lack of integrated zoning and land-use planning and the related loss of biodiversity and natural resources highlight the importance of developing Land Use Plans and Tourism Master Plans. These Plans must reflect national perspectives but should be consistent with regional and global initiatives and realities. Regional collaboration can complement local efforts, facilitating the optimization of the region's human, financial and other resources. Climate change mitigation and adaptation are possible avenues for regional collaboration. Climate change impacts both the length and quality of the tourism season. Climate change influences tourism demand in some regions, because it impacts the natural environment in ways that can either entice or discourage visitors (Simpson et al., 2011). Much of the Region's tourism-related natural resources and infrastructure are located in the coastal zone. These assets are currently threatened because of climate change. For governments, entrepreneurs in the tourism sector, and society as a whole, climate change is a new reality. Increasingly, investors' investments decisions are informed and guided by climate change related risk assessments (Simpson et al., 2011).

The opinions of the participants support the Social Exchange Theory perspective, the theoretical framework used for this study. This theory contends that people estimate the overall value of a specific relationship by deducting its costs from the returns it provides. For this study, the supposition is that returns of growth and development results are primarily financial gains while the costs include social and environmental impacts. Respondents were asked to rate the factors that hinder or negatively impact the development, growth and sustainability of the Region's tourism sector. In addition, they were asked to rate the overall impact of the tourism industry. In this study, the respondents felt that the overall worth of the tourism industry to the Region is positive, thus people are likely to continue to support the industry. This overall result supports the social exchange perspective, i.e. the socio-economic benefits of the tourism industry outweigh the social and environmental costs.

The development of a 'regional tourism master plan' with a focused analysis of the challenges and opportunities available to the Region along with inter-regional development strategies is one recommendations being advanced based on the findings of this study. Each CTO member state has unique characteristics and contexts for tourism development. However, long term tourism sustainability in these states is very dependent upon their ability to strengthen and effectively participate on the regional and international tourism landscape. The development of strong and well-coordinated partnerships between local communities, NGOs, the private sector, regional associations and organizations, and national governments, to promote regional sustainable tourism can contribute towards the realization of that goal. Such 'real' partnerships will provide the platform and environment for the formulation and implementation of clear and concise community-based tourism policies and strategies, adoption of a multidisciplinary perspective, facilitate integrated approach to development, and conceptualization of a widely acceptable regional tourism development and marketing program. Continuous evaluation and monitoring of these collaborative approaches would be critical for long term success.

Another possible avenue for the Region's consideration is the strengthening and promotion of domestic tourism partly because its ability to counteract the seasonal nature of international tourism. Skanavis and Sakellari (2011) indicate that few studies have analyzed the domestic tourism demand probably due to the difficulty in tracking domestic tourists and the strong foreign exchange earnings that are derived from the international tourism industry. Skanavis and Sakellari (2011), however, felt that education was the key to unlocking the potential of domestic tourism for developing countries.

Much of the Region's current tourism products highlight assets such as sun, sea and sand. However, in the long term efforts must be made to enhance and diversify the Region's tourism product, capitalizing on the unique characteristics of member states. An important objective of the proposed partnership should be to ensure that maximum benefits are enjoyed by the local population and that the tourists' experiences remain positive. Obviously, these recommended strategies and approaches must be framed in a long term context, yet must be flexible, credible, and transparent if desired objectives are to be realized. 


\section{Acknowledgements}

The authors are very appreciative of the partial sponsorship and support of the Caribbean Tourism Organization for this study. Partial financial support from the USDA's McIntire-Stennis initiative (Award \# ALAX-011-M409) and USDA-NIFA Capacity Building Grant (Award \# 2012-38821-20067) are also hereby acknowledged. The constructive comments of reviewers were appreciated.

\section{References}

Andereck, K. L., Valentine, K. M., Anshell, M., Knopf, R. C., \& Vogt, C. A. (2005). Residents' perceptions of community tourism impacts. Annals of Tourism Research, 32(4), 1056-1076. http://dx.doi.org/10.1016/j.annals.2005.03.001

Ashley, C., Boyd, C., \& Goodwin, H. (2000). Pro-Poor Tourism: Putting Poverty at the Heart of the Tourism Agenda. London UK: Overseas Development Institute. Retrieved from http://www.odi.org.uk/resources/docs/2861.pdf

Cordero, J. C. M. (2008). Residents' perception of tourism: A critical theoretical and methodological review. Ergo Sum, 15(1), 35-44.

CTO (Caribbean Tourism Organization). (2007). Climate change and tourism in the Caribbean: Threats and opportunities. Paper presented at the Ninth Annual Conference on Sustainable Tourism Development. Caribbean Community Climate Change Center. Grand Cayman, B.W.I. Retrieved from http://www.onecaribbean.org/content/files/UlricTrotzTourism and ClimateChange.pdf

CTO (Caribbean Tourism Organization). (n.d.). Competing with the Best: Good Practices in Community-Based Tourism in the Caribbean. Manual produced by the Caribbean Regional Sustainable Tourism Development Program.

Retrieved

from http://www.onecaribbean.org/content/files/part\%201\%20competiting\%20with\%20best.pdf

Fredline, E., \& Faulkner, B. (2000). Host community reactions: A cluster analysis. Annals of Tourism Research, 27(3), 763-784. http://dx.doi.org/10.1016/S0160-7383(99)00103-6

Getz, D. (1994). Residents' attitudes towards tourism: A longitudinal study in Spey Valley, Scotland. Tourism Management, 15(4), 247-258. http://dx.doi.org/10.1016/0261-5177(94)90041-8

Grandoit, J. (2005). Tourism as a Development Tool in the Caribbean and the Environmental By-products: The Stresses on Small Island Resources and Viable Remedies. Journal of Development and Social Transformation, $\quad 2, \quad 89-97 . \quad$ Retrieved $\quad$ from http://www1.maxwell.syr.edu/uploadedFiles/moynihan/dst/grandoit10.pdf?n=3241

Griffith, W. (2011). State of Caribbean Tourism 2011. Media Conference. Caribbean Tourism Organization, St. Michael, Barbados. Retrieved from http://www.youtube.com/watch? v=hIOZfF-0_cc\&feature=player_embedded

Harrill, R. (2004). Residents' attitudes towards tourism development: A literature review with implications for tourism planning. Journal of Planning Literature, 18(3), 251-266. http://dx.doi.org/10.1177/0885412203260306

Lankford, S. V., \& Howard, D. R. (1994). Developing a tourism impact attitude scale. Annals of Tourism Research, 21(1), 121-139. http://dx.doi.org/10.1016/0160-7383(94)90008-6

Mason, P., \& Cheyne, J. (2000). Residents' attitudes to proposed tourism development. Annals of Tourism Research, 27(2), 391-411. http://dx.doi.org/10.1016/S0160-7383(99)00084-5

Mather, S., \& Todd, G. (1993). Tourism in the Caribbean. [Record Number 19931861132]. Special Report Economist Intelligence Unit.

Milman, A., \& Pizam, A. (1988). Social impacts of tourism on Central Florida. Annals of Tourism Research, 15(2), 191-204. http://dx.doi.org/10.1016/0160-7383(88)90082-5

Nordquist, G. (2006). Patient insurance status and do-not-resuscitate orders: Survival of the richest? Journal of Sociology \& Social Welfare, 33(1), 79-92.

Nurse, K. (2007). Development of a Strategic Business Management Model for the Sustainable Development of Heritage Tourism Products in the Caribbean. Caribbean Regional Sustainable Tourism Development Program, St. Michael, Barbados. from http://www.onecaribbean.org/content/files/CRSTDPHeritage\%20Tourism\%20Report.pdf 
Reiss, R., Schoenig, G., \& Wright, G. (2006). Development of the factors for estimating swimmers' exposure to chemicals in swimming pools. Human and Ecological Risk Assessment, 12(1), 139-156. http://dx.doi.org/10.1080/10807030500430518

Silva, M. (2002). Overview of the Caribbean Tourism Sector: Managing Tourism Resources. Proceedings from Adaptation to Climate Change in the Caribbean Tourism Sector Workshop. Caribbean Tourism Organization, Grenada. Retrieved from www.oas.org/macc/Present/CCTourism

Simpson, M., Scott, D., \& Trotz, U. (2011). Climate Change's Impact on the Caribbean's Ability to Sustain Tourism, Natural Assets, and Livelihoods. TECHNICAL NOTES No. IDB-TN-23. Inter-American Development Bank. Retrieved from http://www.iadb.org/intal/intalcdi/PE/2011/07903.pdf

Skanavis, C., \& Sakellari, M. (2011). International Tourism, Domestic Tourism and Environmental Change: Environmental Education Can Find the Balance. Tourismos: An International Multidisciplinary Journal of Tourism, 6(1), 233-249.

Smith, S. (2012). CTO - State of the Industry News Conference. CTO Headquarters, St. Michael, Barbados.

UNDP (United Nations Development Program). (2009). Assessment of Development Results: Evaluation of UNDP Contribution to Countries of the Organization of Eastern Caribbean States and Barbados. Retrieved from http://web.undp.org/evaluation/documents/ADR/ADR_Reports/Barbados/ADR_Barbados.pdf

UNWTO (World Tourism Organization). (1995). Technical Manual, No 2: Collection of Tourism Expenditure Statistics. World Tourism Organization, Madrid, Spain. Retrieved from http://pub.unwto.org/WebRoot/Store/Shops/Infoshop/Products/1034/1034-1.pdf

UNWTO (World Tourism Organization). (2011). Tourism Highlights 2010 Edition. Retrieved from www.unwto.org/facts/eng/pdf/highlights/UNWTO_Highlights10_en_HR.pdf

UNWTO/ETC (World Tourism Organization/ European Travel Commission). (2011). Handbook on Tourism Product Development. World Tourism Organization (UNWTO) and European Travel Commission (ETC), Madrid Spain. Retrieved from http://pub.unwto.org/WebRoot/Store/Shops/Infoshop/4E6D/E076/AAE5/B827/BFEC/C0A8/0164/205F/11 0907_product_development_excerpt.pdf

Wall, G., \& Mathieson, A. (2006). Tourism: change, impacts and opportunities. Pearson Prentice Hall, Essex.

Williams, J., \& Lawson, R. (2001). Community issues and resident opinions of tourism. Annals of Tourism Research, 28(2), 265-290. http://dx.doi.org/10.1016/S0160-7383(00)00030-X

Zhang, J., R., Inbakaran, J., \& Jackson, M. (2006). Understanding community attitudes towards tourism and host-guest interaction in the urban-rural Border Region. Tourism Graphies, 8(2), 182-204. http://dx.doi.org/10.1080/14616680600585455

\section{Copyrights}

Copyright for this article is retained by the author(s), with first publication rights granted to the journal.

This is an open-access article distributed under the terms and conditions of the Creative Commons Attribution license (http://creativecommons.org/licenses/by/3.0/). 